\title{
The Factors Militating Against Effective Medical Record Documentation. A Case Study of Ekiti State University Teaching Hospital Ado Ekiti
}

\author{
Oluwatuyi Mayowa Funmilayo \\ ${ }^{1}$ University of ibadan, Oyo State, Nigeria. \\ Department of Library, archival management and Information Studies. \\ ${ }^{2}$ Ekiti State College of Health Sciences and Technology Ijero \\ Department of Health Information Management.
}

\begin{abstract}
It has been recognized that effective medical record documentation is affected by prevailing factors militating against health institutions in Nigeria. The Ekiti State University teaching Hospital has track record of competent Health Information officers who utilize different documentation methods, the methods in use are assessed while also identifying the problems or factors militating effective documentation in the EKSUTH. . The sampling technique employed was a random sampling which is a sub-group of people chosen by chance in a way that everyone has the chance of being selected. Thirty questionnaires was distributed and retrieved personally. From the data collected it revealed that the Major factor militating against effective MRD in EKSUTH is inadequate resources, funding while also revealing complaints on non-legibility of physicians handwriting, lack of skilled personnel among others. Based on the findings of this research work, it was concluded that inadequate funding and resources is the main factor militating against effective MRD in EKSUTH. Government should make provision for more facilities and electronic medical record equipment to enhance efficient MRD while also making effort to employ more Health Information professionals to further boost effective MRD in EKSUTH.
\end{abstract}

\section{$>$ Objective:}

This study is done to appraise the contributory factors militating against effective documentation in Ekiti State teaching hospital.

\section{Materials and Methods:}

Structured questionnaire and personal interview of Health Information Professionals in EKSUTH was carried out. The Questionnaire was structured with questions targeted in accordance with the specific objective of this study.

\section{$>$ Results:}

Respondents aged between 26 - 50 years and with Tertiary education as the highest proportion of respondents. The highest respondents blamed the ineffectiveness on inadequate resources although these associations did not reach significant levels. More apportioned the factors to be due to non-legible handwriting of physician.

\section{Conclusion:}

It is recommended that there should be adequate funding and provision of resources needed for effective medical documentation, Training and retraining program and employment of more health record personnel.

Keywords:- MRD, Electronic Health record, Health Data, Coding.

\section{INTRODUCTION}

Health care delivery system is the process of meeting the health care needs of people, institutions, and resources and other target populations. There are numerous health care delivery systems globally. Every country is expected to set up the health delivery system which is up to standard level in terms of health care delivery and services. [3]. The essential health systems consist of primary healthcare which is the health system which consist of planning and distribution of health care needs among market participants and public health care system which is the effort of governments, trade unions, charities, religious organizations, or other co-ordinated bodies to deliver planned health care services targeted to the populations they serve. Health care planning and distribution is evolutionary rather than revolutionary[6]. The World Health Organization defines health systems as a system consisting of all organizations, people and actions directed at promoting, restoring or maintaining health. This includes efforts which influence health determinants and healthimproving activities. A health system encompasses publicly owned facilities which delivers personal health services, health insurance organizations, a mothers care for a sick child at home; vector-control campaigns, efforts of private health care providers; behavior change programmes, occupational health and safety legislation[8]. It also takes into consideration inter sectoral action by health staff, such as enhancing the ministry of education to promote female education which facilitate the growth of good health WHO(2000). Documentation of health care delivery system plays a significant role in providing the needed information regarding the evaluation and treatment of health care services and communicating same to third-party payers. Documentation guidelines serve as the standard for many other insurance plans[11]. Documentation also provides relevant clinical information. It is essential that the 
ISSN No:-2456-2165

documents note and reports are clear, legible and that it efficiently conveys all of the essential information required for clinical management and reimbursement[12]. The study seeks to proffer an appraisal of the factors militating against effective documentation in health delivery system in EKSUTH. World Health Organization defines health systems as a system consisting of all organizations, people and actions directed at promoting, restoring or maintaining health. This includes efforts which influence health determinants and health-improving activities. A health system encompasses publicly owned facilities which delivers personal health services, health insurance organizations, a mother's care for a sick child at home; vector-control campaigns, efforts of private health care providers.

\section{Statement of the Problem}

The challenge facing documentation relates to certain factors inadequate skilled manpower, lack of efficient technology, lack of financial resources to adopt modern technology which promote effective documentation, lack of information technology skill among others. Consequently the problem confronting the study is to appraise the factors militating against effective documentation in health delivery system in Ekiti State University Teaching Hospital Ado Ekiti.

\section{$>$ Objectives of the Study}

The Main Objective of the study is to appraise the factors militating against effective documentation in health delivery system. A case study of EKSUTH Ado Ekiti; The specific objectives include: To find out if there are proper documentations of health delivery system in Ekiti State University Teaching hospital. To investigate the impacts of effective documentation of health delivery system in Ekiti State University Teaching Hospital. To identify the factors militating against effective documentation of health delivery system in Ekiti State University Teaching Hospital.

\section{Research Questions}

- Are there proper documentations of health delivery system in Ekiti State University Teaching hospital?

- What are the impacts of effective documentation of health delivery system in Ekiti State University Teaching Hospital?

- What are the factors militating against effective documentation of health delivery system in Ekiti State University teaching hospital?

\section{METHODOLOGY}

\section{$>$ Study Area}

Ekiti State University Teaching Hospital is located at Ado-Iworoko-Ifaki Road, Ado Ekiti, Ekiti This was established in 2008. Built by the State Government in 2008. Formerly known as The University Teaching Hospital, this is a tertiary health facility affiliated with Ekiti State University, that provides secondary and tertiary medical care, and is also involved in the training of high and middle level manpower for the health industry.
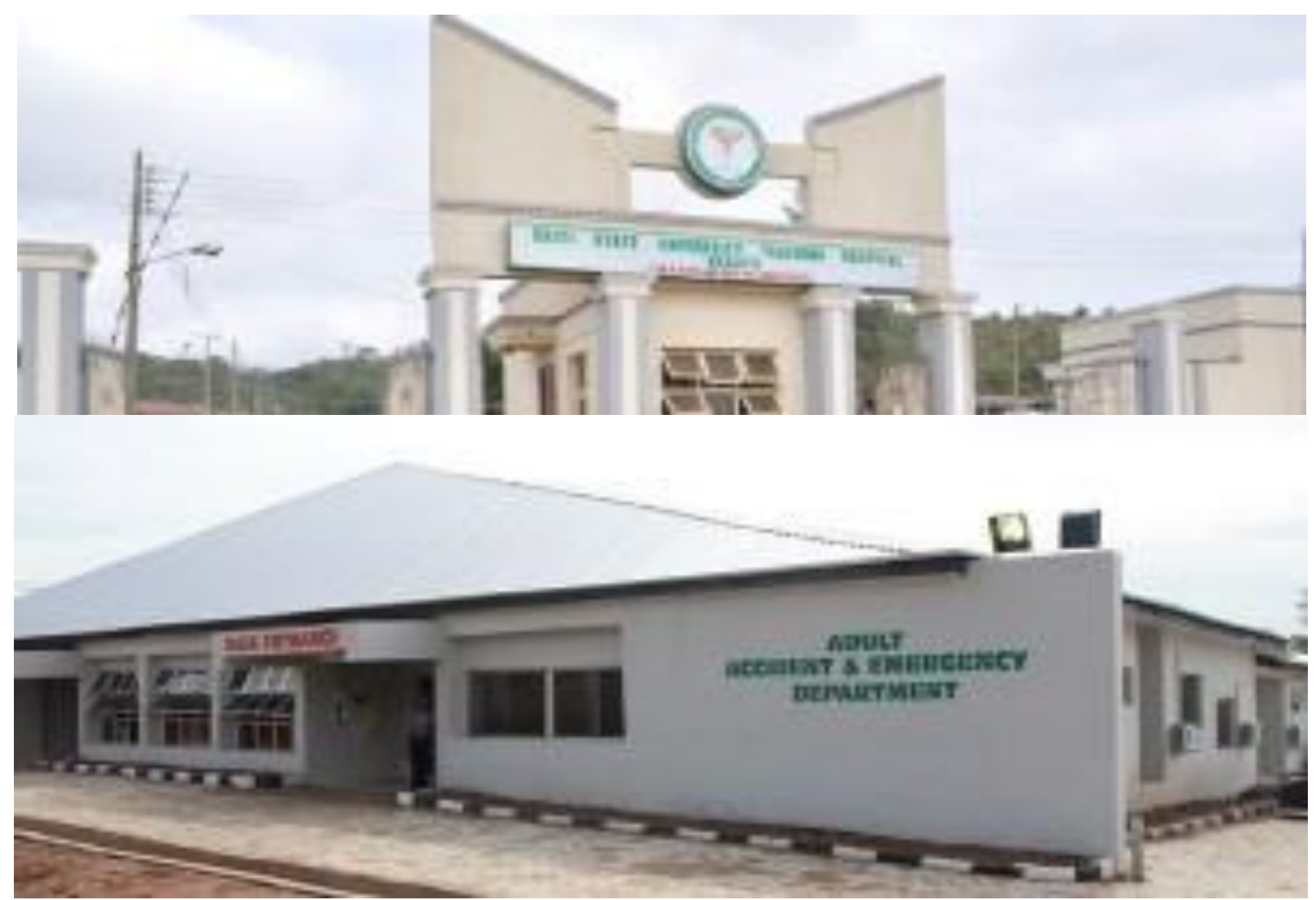

Fig 1 


\section{Population of the Study}

The Health Information Management Department

Health Record Officer $=13$

Health Record Technician $=50$

Health Record Asst. $=2$

Total $=65$

\section{Sampling}

The sampling technique employed was a simple random sampling which is a subset of individuals chosen randomly and entirely by chance such that each individual has the same probability of being selected in the sample. Thirty questionnaires was distributed and retrieved personally.

\section{RESULT}

Table 1 shows Age, Sex, Education and Grade level of Medical Record Professionals sampled in EKSUTH.

\begin{tabular}{|c|c|c|c|c|}
\hline & AGE & SEX & EDUCATION LEVEL & GRADE LEVEL \\
\hline RANGE & $26-50$ & FEMALE & TERTIARY & $7-10$ \\
\hline HIGHEST & 23 & 17 & 30 & 26 \\
FREQUENCY & & & 100 & 86.6 \\
\hline PERCENTAGE & 76.6 & 56.6 & Table 1
\end{tabular}

Table 2 shows

- Responses on the method of MRD in EKSUTH

- Wether MRD in EKSUTH is reviewed in Chronological order

- Wether MRD in EKSUTH reveal continuum patient care

- Wether MRD is done effectively in EKSUTH

\begin{tabular}{|c|c|c|c|c|}
\hline & $\begin{array}{c}\text { MEANS OF MRD } \\
\text { IN EKSUTH }\end{array}$ & $\begin{array}{c}\text { MRD IN EKUSTH } \\
\text { REVEIWED IN } \\
\text { CHRONOLOGICAL ORDER? }\end{array}$ & $\begin{array}{c}\text { MRD IN EKUTH } \\
\text { REVEAL CONTINUM } \\
\text { PATIENT CARE? }\end{array}$ & $\begin{array}{c}\text { MRF DONE } \\
\text { EFTIVELY IN } \\
\text { EKSUTH? }\end{array}$ \\
\hline RESPONSE & BOTH & YES & YES & \\
\hline HIGHEST & MLCTRONIC AND & & 30 & \\
FREQUENCY & 24 & 30 & YES \\
\hline PERCENTAGE & 80 & 100 & YES & \\
\hline
\end{tabular}

Table 2

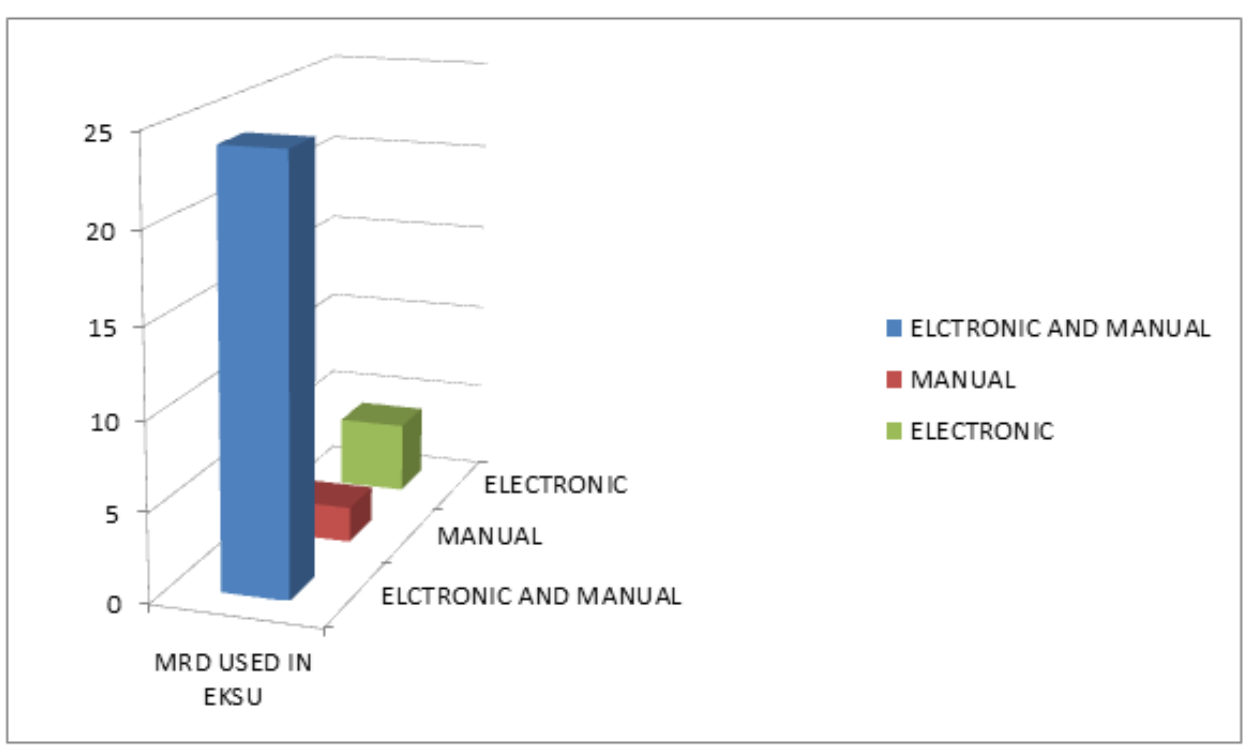

Fig 2:- shows the method of MRD in use in EKSUTH 
ISSN No:-2456-2165

Table 3 Shows responses on the rating of MRD in EKSUTH, The impact of Poor MRD, Factors militating against effective MRD in EKSUTH and possible solutions.

\begin{tabular}{|c|c|c|c|c|}
\hline & $\begin{array}{c}\text { RATING MRD IN } \\
\text { TERMS OF } \\
\text { EFFCTIVENESS } \\
\text { AND EFFICIENCY } \\
\text { IN EKSUTH }\end{array}$ & $\begin{array}{c}\text { IMPACT OF POOR } \\
\text { MRD IN EKSUTH }\end{array}$ & $\begin{array}{c}\text { FACTROS } \\
\text { MILITTATING } \\
\text { AGAINST } \\
\text { EFFECTIVE MRD } \\
\text { IN EKSUTH }\end{array}$ & $\begin{array}{c}\text { SOLUTIONS TO } \\
\text { ENHANCE } \\
\text { EFFCETIVE MRD } \\
\text { IN EKSUTH }\end{array}$ \\
\hline RESPONSE & $\begin{array}{c}\text { EFFECTIVE BUT } \\
\text { NOT EFFICIENT }\end{array}$ & $\begin{array}{c}\text { POOR FOLLOW UP } \\
\text { TREATMENT }\end{array}$ & $\begin{array}{c}\text { INADEQUATE } \\
\text { RESOURCES }\end{array}$ & $\begin{array}{c}\text { ADEQUATE } \\
\text { FUNDING AND ON } \\
\text { THE JOB TRANING } \\
\text { PROGRAM }\end{array}$ \\
\hline FREQUENCY & 22 & & & 21 \\
\hline PERCENTAGE & 73.3 & 18 & 56.6 & 70 \\
\hline
\end{tabular}

Table 3

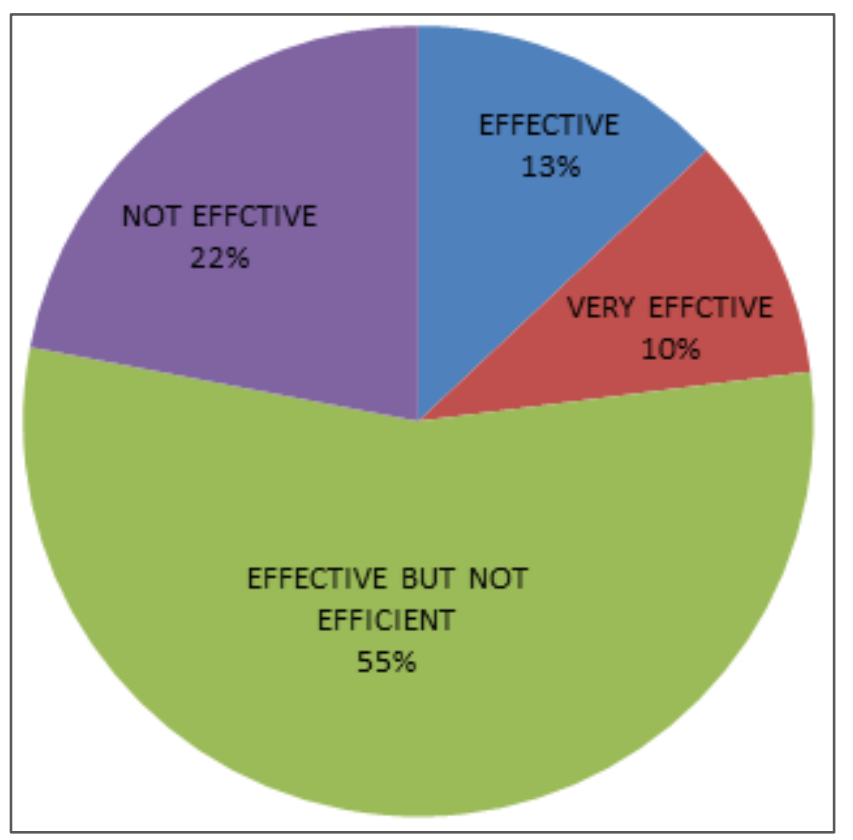

Fig 3:- Shows the Effectiveness and Efficiency Measurement in Eksuth

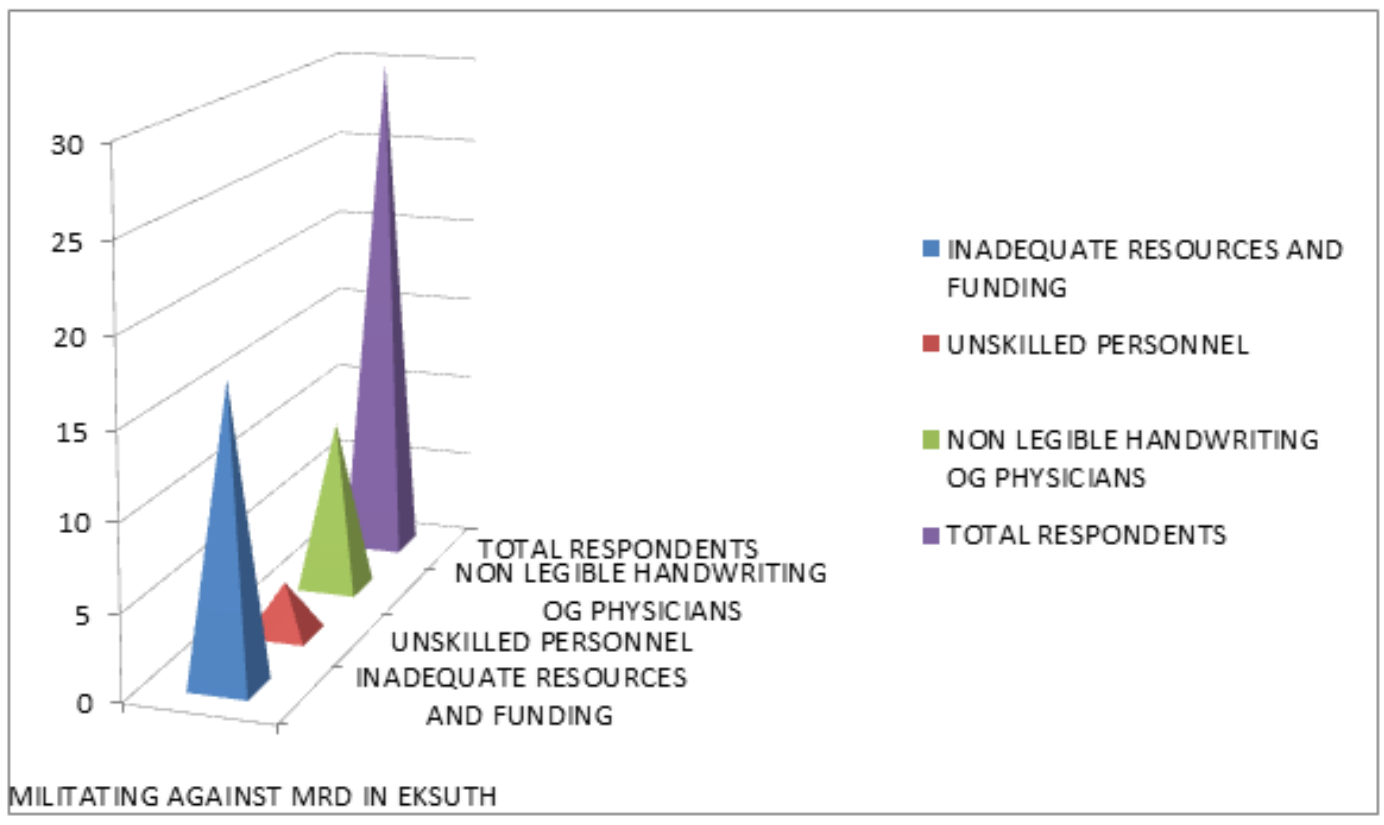

Fig 4:- Shows Responses on Factors Militating Against Effective Mrd in Eksuth. 


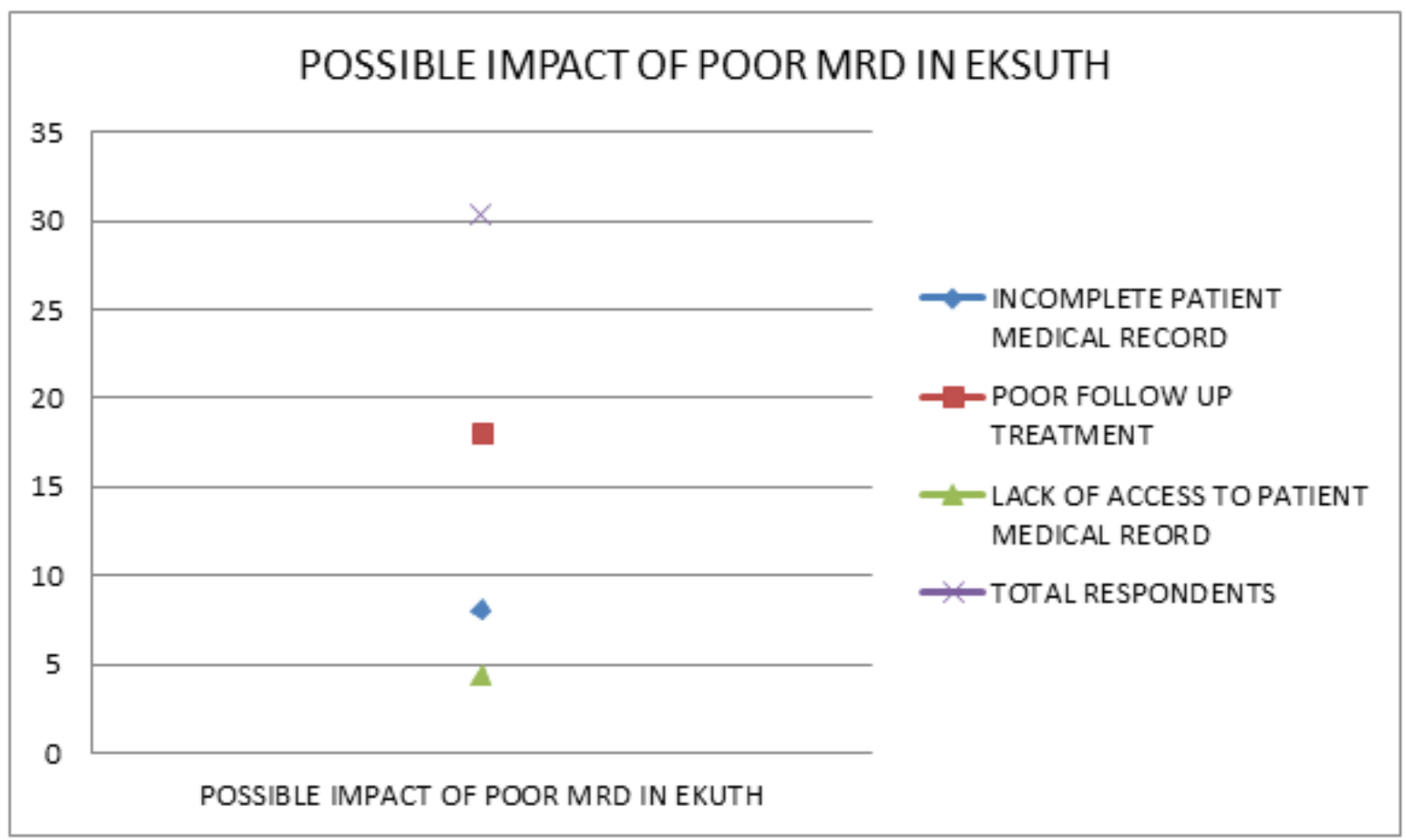

Fig 5:- Shows Responses on the Possible Impact of Poor Mrd in Eksuth

\section{DISCUSSION}

This study showed that the method of documentation used in EKSUTH is both Electronic and Manual with the highest number of the respondent in agreement on the importance of MRD in health care system. MRD in EKSUTH is reviewed in chronological order and it reveals continum in patient care. A visit to some departments, the assessment shows a level of effective MRD in EKSUTH with the highest confirming the claim of MRD in EKSUTH being effective but not efficient. It was also noted that poor MRD could lead to poor follow up treatment, lack of access to patient medical record and incomplete medical record of patient. From the data collected it revealed that the Major factor militating against effective MRD in EKSUTH is inadequate resources, funding while also revealing complaints on non-legibility of physicians handwriting, lack of skilled personnel among others.

\section{CONCLUSION}

Based on the findings of this research work, it was concluded that inadequate funding and resources is the main factor militating against effective MRD in EKSUTH. Government should make provision for more facilities and electronic medical record equipment to enhance efficient MRD while also making effort to employ more Health Information professionals to further boost effective MRD in EKSUTH.

\section{REFERENCES}

[1]. Personal Health Records. CMS. April 2011. [cited 2015September 22].

[2]. Karp David, Huerta JM, Dobbs Claudia A, DukesDorothy 1, Kenady Kathy. Medical Record Documentationfor Patient Safety...MIEC. [cited 2015 Sept 21]; Availablefrom: URL:http://www.miec.com/Portals/0/pubs/MedicalRe c.pdf

[3]. Law and Physician Homepage. Medical Records inLitigation. [cited 2015 Sept 21]; Available from: URL:http://biotech.law.lsu.edu/Books/lbb/x187.htm

[4]. Deepender Deswal, TNN. The Times of India. Haryanadoctors doctor 'legal' reports 2010 Dec 6; [cited 2015September 23]; Available from: URL:http://timesofindia.indiatimes.com/india/Haryan a-doctors-doctor-legalreports/articleshow/7050516.cms

[5]. Thaindian News. Doctor jailed for issuing fake medicalcertificates. 2008 December 6 by IANS [cited 2015 July4]; Available from: URL:http://www.thaindian.com/newsportal/uncategor ized/doctor-jailed-for-issuing-fake-medicalcertificates_100127982.html

[6]. Medico-legal helpline [24X7 helpline]. Maintenance ofMedical records. 2008 June 15; [cited 2015 September22]; Available from: URL:http://medicolegalhelpline.blogspot.in/2008/06/ maintenance-of-medical-records.html

[7]. Tiwari Satish, Baldwa Mahesh, Tiwari Mukul, KutheAlka. Textbook on Medicolegal Issue. 1st ed. NewDelhi: Jaypee Brothers Medical Publishers (P) Ltd;2012. p. 49-52. 
[8]. A Sample Health Record. Nlm.nih.gov. 2012-04-14. [cited2015 September 22]; Available from: URL:https://en.wikipedia.org/wiki/Medical_record\#ci te_note-7

[9]. HC Division Bench of Justice, Satish Kumar Mittal andJustice, M. Jeyapaul, P \& H High Court.

[10]. Malathy Iyer. The Times of India. Write all prescriptionsin capital letters, Mumbai citizens tell doctors. 2012May 20, 01.26AM IST. [cited 2015 July 4]; Available from: URL:http://timesofindia.indiatimes.com/city/mumbai/ Write-all-prescriptions-in-capital-letters-Mumbaicitizens-tell-doctors/articleshow/13308546.cms

[11]. Mahanta Putul. Medical Law and Ethics. In: ModernTextbook of Forensic Medicine and Toxicology. 1st ed.New Delhi; Jaypee Brothers Medical Publishers (P) Ltd;2014. p. 34.12

[12]. Gutheil TG. Paranoia and progress notes: A guide to forensically informed psychiatric record keeping. Hosp Community Psychiatry. 1980;31:479-82. [PubMed] [Google Scholar]

[13]. Gutheil TG. The medical record in the acute care setting and issues of confidentiality. In: Sederer LL, Rothschild AJ, editors. Acute care psychiatry: Diagnosis and treatment. Baltimore: Lippincott, Williams and Wilkins; 1997. [Google Scholar] 